\title{
Publisher Correction: Improved TMC1 gene therapy restores hearing and balance in mice with genetic inner ear disorders
}

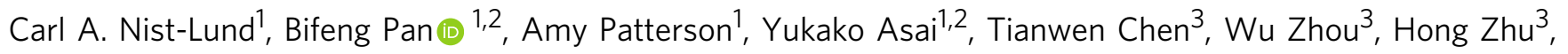
Sandra Romero ${ }^{4}$, Jennifer Resnik ${ }^{2,4}$, Daniel B. Polley ${ }^{2,4}$, Gwenaelle S. Géléoc ${ }^{1,2} \&$ Jeffrey R. Holt ${ }^{1,2,5}$

Correction to: Nature Communications; https://doi.org/10.1038/s41467-018-08264-w, published online 22 Jan 2019.

The original version of this Article contained errors in Fig. 5. In panels $\mathrm{i}$ and $\mathrm{j}$ the three rightmost $x$-axis labels inadvertently read 'Tmc1' instead of 'Tmc2'. These errors have been corrected in both the PDF and HTML versions of the Article.

Published online: 08 February 2019

\begin{abstract}
(c) Open Access This article is licensed under a Creative Commons Attribution 4.0 International License, which permits use, sharing, adaptation, distribution and reproduction in any medium or format, as long as you give appropriate credit to the original author(s) and the source, provide a link to the Creative Commons license, and indicate if changes were made. The images or other third party material in this article are included in the article's Creative Commons license, unless indicated otherwise in a credit line to the material. If material is not included in the article's Creative Commons license and your intended use is not permitted by statutory regulation or exceeds the permitted use, you will need to obtain permission directly from the copyright holder. To view a copy of this license, visit http://creativecommons.org/licenses/by/4.0/.
\end{abstract}

(C) The Author(s) 2019

\footnotetext{
${ }^{1}$ Department of Otolaryngology and F.M. Kirby Neurobiology Center, Boston Children's Hospital, 300 Longwood Avenue, Boston, MA 02115, USA. 2 Department of Otolaryngology, Harvard Medical School, Boston, MA 02139, USA. ${ }^{3}$ Department of Otolaryngology and Communicative Sciences, University of Mississippi Medical Center, Jackson, MS 39216, USA. ${ }^{4}$ Eaton-Peabody Laboratories, Massachusetts Eye and Ear Infirmary, Boston, MA 02139, USA. ${ }^{5}$ Department of Neurology, Boston Children's Hospital, Harvard Medical School, Boston, MA 02115, USA. Correspondence and requests for materials should be addressed to J.R.H. (email: jeffrey.holt@childrens.harvard.edu)
} 